\title{
CROSSCULTURAL COMMUNICATION IN ENGLISH-SPEAKING COMMUNITIES: SPEECH ACTS OF COMPLIMENTING
}

\section{Solodka A. K., Luis Perea}

\section{INTRODUCTION}

Speech acts take an important role in communication. Austin defines speech acts as the minimal unit of communication. Austin divides speech acts into locutionary, illocutionary and perlocutionary acts ${ }^{1}$.

One of the most interesting acts to study is complimenting. Herbert studies speech acts such as compliments and compliment responses because there is not an agreement or a common pattern on what is the correct way of complimenting and responding to a compliment, even within the same speech community. Holmes claims that a compliment is: "a speech act which attributes credit to someone other than the speaker, usually the person addressed for some 'good' possession, characteristic, skill etc."'

At the same time, communication in foreign language sometimes is strictly technical by using grammar, syntax, morphology, phonetics, phonology. It omits a very important cultural part of languages. Such a lacking part is the speech acts and the appropriate pragmatic knowledge to really obtain good crosscultural communication.

People who only know the technical part of the language may not understand a large percentage of a conversation or how speech acts work. All this implies knowing how to communicate in social contexts appropriately. Communicators need what Canale \& Swain explain as sociolinguistic competence which is the component made up of two sets of rules: "sociocultural rules of use and rules of discourse", and strategic competence which is the "component that consists of verbal and nonverbal communication strategies that may be called into action to compensate for breakdowns in communication due to performance variables or to insufficient competence" ${ }^{3}$.

\footnotetext{
${ }^{1}$ Austin J. L. (1975) How to Do Things with Words, Second Edition, Oxford: Oxford University Press, p. 24.

2 Holmes J. (1988) Paying compliments: A sex preferential positive politeness strategy. Journal of Pragmatics, no. 12 (3), p. 446.

3 Canale M. \& Swain M. (1980) Theoretical bases of communicative approach to second language teaching and testing. Applied Linguistics, no. 1, p. 29.
} 
All this together forms what is called communicative competence; which enables the speaker to produce and to understand and infinite set of sentences appropriately and accurately. Communicative competence includes pragmatic competence. Pragmatics analyzes and studies the conversation and the speech acts, in a general way, the functions of the linguistic sentences and their characteristics in the communication processes are also studied (Van Dijk).

Pragmatic competence is learnt by individuals when they obtain their first language. Pragmatic competence is defined by Thomas and Nordquist, as the ability to use language successfully in order to achieve a specific purpose and to understand language in context; Thomas also states that "pragmatic competence in these situations is very important because without

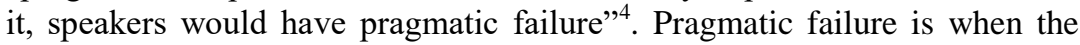
utterance has totally failed to achieve the speaker's goal; it is also defined as the language learners' inability to understand what is meant by what is said (Nordquist).

The aim of this research is to define the ways of complimenting in Ukrainian, Russian and American English to avoid misunderstandings and pragmatic failure. To achieve this goal, the following tasks were set out: to compare American, Ukrainian and English compliments in order to know the patterns being used by the speakers, as well as to find what are the similarities and differences in: (compliment frequency; attributes praised; role relationship between the speakers; gender of the speakers; tone used and compliment form that includes: number of words, adjectives and verbs used in the compliments).

\section{Theoretical background of the research \\ Pragmatics and pragmatic competence}

As it was mentioned before, second language learners besides having the grammatical knowledge; they need the knowledge of the appropriate use of language in a context and the sociolinguistic rules of a speech community, all this is concerned with the study of Pragmatics. Additionally, if a second language speaker wants to understand an utterance in the target language, he/she needs pragmatic competence that is the knowledge needed to determine what sentences mean when they are spoken in a certain way and context (Fraser).

Pragmatics is the study of linguistic interaction between people (Wierzbicka). Pragmatics analyzes the conversation and the speech acts (Nordquist). In a general way, it studies "the functions of the linguistic

\footnotetext{
${ }^{4}$ Thomas J. (1983) Cross-cultural pragmatic failure. Applied Linguistics, no. 4, p. 91.
} 
sentences and their characteristics in the communication processes as well as the language use in a context and in particular situations",5.

Fraser explains pragmatic competence as "the knowledge to determine the meaning of any sentence depending on when it is spoken, the way and the specific context" ${ }^{\prime \prime}$. Also, any time a speaker uses the language in a social context, he/she is performing one or more speech acts such as: requesting, complimenting, declaring, apologizing, criticizing, etc. So when they are expressing such speech acts, they are showing their pragmatic competence (Fraser; Kasper).

According to Bialystok, pragmatic competence is "the ability to use and interpret language in contexts" ". Bialystok also mentions the speaker's ability to use language for different purposes and the listener's ability to understand the real intention of the speaker.

Thomas postulates that "it is the ability to use language successfully in order to achieve a specific purpose and to understand language in context" ${ }^{\text {" }}$. Thomas also concerns that pragmatic competence in these situations is very important because without this, speakers would have pragmatic failure. Consequently, the results are misunderstanding, communication breakdowns, frustration etc. (Beebe, Takahashi \& Uliss-Weltz; Nguyen, Pham, \& Pham; Farshi, \& Baghbani; Loiseau, Hallal, Ballot, \& Gazidedja).

Thomas states that pragmatic patterns are important to be able to use the appropriate utterances in a context, in addition if a hearer wants to understand and interpret what the speaker intended through his utterance, such a hearer must take into account both "contextual and linguistic cues", According to Thomas, there are "2 kinds of pragmatic failure: pragmalinguistic failure that occurs when speech acts are inappropriately transferred from L1 to L2 and sociopragmatic failure which refers to the social conditions placed on language in use, it also covers patterns such as social distance, gender and intimacy of relationship" ${ }^{\prime 0}$.

All the situations which cause misunderstandings, are transferring the inappropriate form of language from L1 to L2 (Wolfson; Solak \& Bayar). That is the reason why speech acts, speech events and pragmatic competence

5 Van Dijk T. (1985) Handbook of Discourse Analysis, London: Academic Press, p.81.

${ }^{6}$ Fraser B. (1990) Perspectives on Politeness. Journal of Pragmatics, no. 14, p. 221.

7 Bialystok E. (1993) Symbolic representation and attentional control in pragmatic competence. In Kasper, G., \& Blum-Kulka, S. (Eds.). Interlanguage Pragmatics (p. 43-57). Oxford: Oxford University Press, p. 44.

${ }^{8}$ Thomas J. (1983) Cross-cultural pragmatic failure. Applied Linguistics, no. 4, p. 92.

${ }^{9}$ Ibid., p. 98.

${ }^{10}$ Ibid., p. 99. 
are important to understand the reasons which provoke pragmatic failure (Shi). And it is helpful to conduct cross-cultural research to investigate student's L1 strategies (Rajabi \& Farahian; Halenko \& Jones; Allami \& Naeimi). Finally, pragmatic competence plays an important role in the acquisition of a language because speakers avoid pragmatic failure and it helps to understand the meaning and purpose of the utterance in any context.

\section{Compliments}

The speech act of complimenting in this study was selected because Ukrainian and Russian L2 learners of English get confused when they try to make or understand a compliment in a different way than native speakers do. In addition, it is essential to mention the fact that sometimes some of those expressions in both languages are part of the personal or regional way of expressing in those places; all this leads to the slang in the USA. (Nelligan).

Aceves in her study of compliments, states that the study of the compliment speech act contributes "valuable information that concerns when and how and to whom, one may offer a compliment as well as how to interpret implicit social and cultural meanings; and how to respond appropriately when one receives a compliment. Compliment as a general term means giving praise, credit, eulogy, to a person for any possession, characteristics, skill, etc." 11

Chung-Hye defines a compliment as "a speech act which explicitly or implicitly attributes credit to someone other than the speaker, usually the person addressed, for 'good' (possession, characteristics, skill etc.) which is positively valued by the speaker and the hearer" 12 .

Manes defines compliments as those speech acts which have the reflection and expression of cultural values because of their nature as judgments, over expressions of approval or admiration of another's work, appearance or taste.

Holmes suggests three functions of compliment exchanges. (1) That compliments are usually used as mean of expressing liking when used as positive affective speech acts. In other words, compliments allow increase solidarity between people. Example: How nice you look today! (2) That compliments can serve as positive politeness strategies before a face threatening act (FTA). All this means that a compliment can be used in a very stressed situation in order to obtain something; a compliment is used

${ }^{11}$ Aceves P. (1996) A Comparative Study of the Use of "Compliments" by Native Speakers of American English and Native Speakers of Mexican Spanish, Puebla: Universidad de las Americas, p. 21.

${ }^{12}$ Chung-Hye H. (1992) A comparative study of compliment responses: Korean females in Korea interactions and in English interactions. Working Papers in Educational Linguistics, no. 8 (2), p. 18. 
before asking what you want. Example: Doesn't your hair look wonderful! By the way, could I borrow your Spanish book? (3) That compliments may be face threatening acts themselves as they indicate an intrusive desire on the speaker's part towards the hearer's possessions. As a consequence, the compliment will be included in the request. Example: can I borrow your wonderful Spanish book? ${ }^{13}$.

Another author who states the importance of the compliments is Bolton, and he proposes three conditions for a compliment to be performed:

1. Hearer has certain quality $Q$.

2. Speaker believes $\mathrm{Q}$ is admirable.

3. Speaker wants hearer to know/believe that speaker admires $Q$.

In addition, Manes claims that "the major function of the compliments is the establishment or reinforcement of solidarity between the speaker and the addressee as well as they play an important role because make possible judgments, expressions of approval or admiration of another's work" ${ }^{14}$.

Finally, Wolfson concludes that "compliments are also windows through which we can view what is valued by a particular culture"15. For instance: In the United States, Americans complement each other on personal appearance, new acquisition and work, suggesting that Americans value these attributes. In Japan, people are more apt to compliment skill and study, suggesting that Japanese people value skill and study. However, in Mexico, people is less expressive that Americans, suggesting that Americans were more expressive than Mexicans.

Wolfson and Manes note different cultural differences in complimenting and observe that Iranians and Arabic speakers tend to use proverbs and other ritualized expressions when complimenting. Al Rawashdeh Al Balqa, investigating Arabic Jordanian compliments (Mujamaleh) and politeness expressions versus their counterparts in American English, shears these ideas. Holmes \& Brown state than American people like to compliment in a very frequent way.

Nelson, Al-Batal, \& Echols compare Egyptian Arabic and American English compliments by using a similar methodology used by Wolfson \& Manes. They find that American compliments are shorter and less complicated than Egyptian compliments. Egyptians use a lot of similes and

13 Holmes J. (1988) Paying compliments: A sex preferential positive politeness strategy. Journal of Pragmatics, no. 12 (3), p. 451.

14 Manes J. (1983) Compliments: A mirror of cultural values. In N. Wolfson and E. Judd (Eds.), Sociolinguistics and Language Acquisition (pp. 82-95). Rowley, MA: Newbury House, p. 18.

${ }^{15}$ Wolfson N. (1988) The bulge: a theory of speech behavior and social distance. In Fine, J. (ed) Second Language Discourse: A Textbook of Current Research, p. 19. 
metaphors and long series of adjectives in complimenting as well as their compliments are less frequent than the American ones.

Aceves and Perea-Hernandez study on Spanish compliments using the methodology employed in Barnlund \& Araki.

Nelson conducted a study of Mexican Spanish and American English compliments. The differences are related to gender. Also, American males compliment another male on appearance even more than Mexican males. Another factor is the fact that Mexican females are more frequently compliment more than American females by males. American females and males compliment acquaintances more than Mexicans. Also, intimates are complimented by Mexican females even more than intimates being complimented by American females.

\section{Methods and materials of research \\ Method of data collection}

This study is based on ethnomethodology to collect data because it will research compliments on a day to day interaction. Valdes, Holmes \& Brown, Wolfson, Herbert, Herbert \& Straight and others use ethnomethodology to collect their data about speech acts.

Ethnography is described by Fetterman as "the art and science of describing a group or culture" 16 . The ethnographer is concerned about people's daily lives, thus, "the most important element of fieldwork is being there - to observe, to ask questions, and to write down what is seen and heard" ${ }^{\prime 17}$. The method is essentially to work with people in their natural contexts.

The present study uses a method that was adapted owing to its necessities and circumstances because two different cultures (Ukrainian and American) and three different languages (Ukrainian, Russian and American English) are compared.

Also, as these techniques and instruments have their advantages and disadvantages, they are used to collect data because they have proven effectiveness in gathering data on compliments. However, it is often argued that speech acts should be studied in their natural contexts using ethnomethodology, it is difficult for cross-cultural studies due to problems of comparability. For this reason, the present study uses a method which was developed by Barnlund \& Araki (1985), also used and expanded by Nelson (1993) and to collect the compliment data.

\footnotetext{
${ }^{16}$ Fetterman D. M. (1989) Ethnography Step by Step, Newbury Park, CA. Sage, p. 11.

${ }^{17}$ Ibid., p. 19.
} 


\section{Subjects}

81 American participants (USA), 179 Ukrainian speakers of Russian (Ukraine) and 118 Ukrainian speakers (Ukraine) participated in the online survey via SurveyMonkey. The Ukrainian participants consisted of university students, professors and people from all over Ukraine including cities such as Mykolaiv, Kiev, Odessa, Lviv, Chernivtsi, etc. from middle class between ages 15-60 years old approximately.

The American participants consisted of university students, professors and people from all over the USA and some people living overseas. They were middle class between ages 16-70 years old. The universities students belong were from: Portland State University, George Fox University, University of Texas at San Antonio, University of the Incarnate Word and several cities from the USA.A small source of data collection consisted from finding compliments in the social media (Facebook), TV, Movies, etc.

\section{Instrument}

An interview is developed to collect the data. First of all, it is necessary to mention that the interview designed by other researchers in collecting compliments, was taken as reference in this study because it gave successful results. Such an interview is taken from the studies of Aceves \& Nelson, and it was adapted and added more information considering the necessities and the subjects of the present study.
A. Characteristics of the interview:
- Open questions.
- English/Russian/Ukrainian version - 26 questions
- Personal information of the participants.
- Variables or aspects studied.

\section{B. Questions of the interview:}

1. Interviewed person - Do not include your real name (Please use a pseudonym that identifies your gender; e. g. Mary or John, etc.)

2. Please select your gender

3. Place of birth (state or region and city) and Age.

4. To what socio economic level do you consider yourself? (Upper level class, middle class, etc.) and where do you currently live?

5. What is the last compliment that you have given to somebody else? What were your exact words?

6. About what did you comment on?

7. What tone did you use?

8. How long ago did you say the compliment?

9. Which is your relationship with the person who received the compliment?

10. The person who received the compliment was male, female or a group of people? 
11. What was the approximate age of the person who received the compliment?

12. What is the last compliment that you have received, and what were the exact words?

13. What kind of tone did the person who told you the compliment use?

14. What was the point of the person who told you the compliment?

15 . When did you receive the compliment?

16. The person who told you the compliment was male or female?

17. What was the approximate age of the person who told you the compliment?

18. Which is your relationship with the person who told you the compliment?

19. What is the last compliment that you have heard someone else tell to someone else?

20. What were the exact words?

21. About what did those persons comment on?

22. What tone was used?

23. When did you last listen to the compliment?

24 . Which was the relationship between those persons?

25 . The person who received the compliment was male, female or a group of people?

26. The person who gave the compliment was male or female?

27. What were the approximate ages of the people who complimented each other?

Correspondence of variables to the questions of the interview was the following: compliment form - questions 5, 12, 19; attributes praised - questions $6,14,20$; relationship between giver and receiver - questions $9,18,23$; gender of the compliment giver and receiver - questions $10,16,22,24,25$; frequency of compliments - questions 8, 15, 22; tone used-questions 7, 13, 21 .

\section{Data analysis}

The compliments are coded sociolinguistically. First it is coded the data and established the categories, which are data driven (the categories are based on the data that is gathered) and based on the studies of Aceves, Nelson, Wolfson, \& Manes. The categories are established according to similar patterns found in their studies.

\section{Results and discussion}

The analysis was made on the data that included: 445 Russian, 231 Ukrainian and 245 English compliments. Participants consisted of native speakers of English interviewed in the United States and native speakers of Russian and Ukrainian from all over Ukraine. 
Average age of participants. Average age of Russian speaking participants was 25.7 years old, Ukrainian speaking participants - 26 years old, English speaking participants -31 years old.

\section{Compliment form}

Compliment form is the language used to express the compliment. The Ukrainian, Russian and American compliments shared similarities in form, and the majority of them were short and adjectival. The following table shows the examples of compliment forms' similarities.

Table 1

Similarities of compliment forms

\begin{tabular}{|c|c|c|}
\hline Russian & Ukrainian & English \\
\hline $\begin{array}{l}\text { PRON+HAVE+ADJ+ } \\
\text { N/NP } \\
\text { Example: } \\
\text { У тебя красивые глаза } \\
\text { (You have beautiful } \\
\text { eуеs). }\end{array}$ & 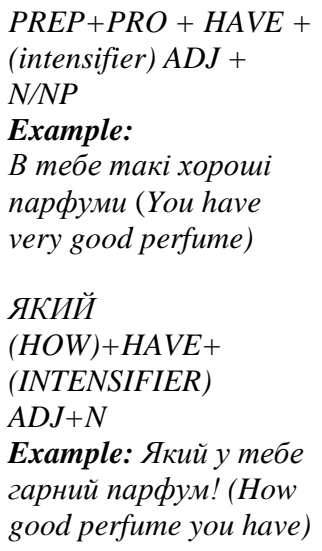 & $\begin{array}{l}P R O+H A V E+A D J+N P \\
\text { Example: } \\
\text { Wow, you have very } \\
\text { white teeth. }\end{array}$ \\
\hline $\begin{array}{l}\text { PRO+ADV(intensifier)+ } \\
\text { ADJ } \\
\text { Example: } \\
\text { Tbl очень умный. } \\
\text { (Yои are very clever.) } \\
\text { PRO+ADJ } \\
\text { Example: Tbl красивая. } \\
\text { (Yoи are beautiful.) }\end{array}$ & $\begin{array}{l}\text { PRO + (intensifier) }+ \\
\text { ADJ } \\
\text { Example: } \\
\text { Він дуже влучний } \\
\text { (Не is very aсcиrate })\end{array}$ & $\begin{array}{l}\text { PRO+BE+ADJ+COMP } \\
\text { LEMENT } \\
\text { Example: You will be } \\
\text { successful anywhere } \\
\text { you go }\end{array}$ \\
\hline $\begin{array}{l}\text { PRO+LOOK+ADV } \\
\text { Example: } \\
\text { Она выглядит } \\
\text { изумительно. } \\
\text { (She looks gorgeous!) }\end{array}$ & $\begin{array}{l}\text { PRO/ADV+LOOK } \\
\text { Example: } \\
\text { Класно виглядаєи } \\
\text { (You look cool) }\end{array}$ & $\begin{array}{l}\text { PRO/NP+LOOK+ } \\
\text { ADJ+COMPLEMENT } \\
\text { Example: } \\
\text { You look beautiful } \\
\text { today. Like a model! }\end{array}$ \\
\hline
\end{tabular}


Table 1 (ending)

\begin{tabular}{|c|c|c|}
\hline Russian & Ukrainian & English \\
\hline $\begin{array}{l}\text { ADJ } \\
\text { Example: } \\
\text { Милая. (Pretty.) }\end{array}$ & $\begin{array}{l}\text { ADJ }(+) \\
\text { Example: } \\
\text { Розумний (Smart) }\end{array}$ & $\begin{array}{l}A D J+N P \\
\text { Example: } \\
\text { Great job! }\end{array}$ \\
\hline $\begin{array}{l}\text { I like/love+ } \\
\text { (intensifier) + your }+N \\
\text { Example: } \\
\text { Мне нравится твоя } \\
\text { обувь. } \\
\text { (I like your shoes.) }\end{array}$ & $\begin{array}{l}\text { I LIKE (YOUR)+N } \\
\text { Example: } \\
\text { Мені дуже } \\
\text { подобається твоя } \\
\text { зовнішність } \\
\text { (I like your арреarance } \\
\text { so тисh) }\end{array}$ & $\begin{array}{l}\text { I+ like/love }+N P \\
\text { Example: } \\
\text { I really like your } \\
\text { neighborhood! }\end{array}$ \\
\hline $\begin{array}{l}P R O+A D V+V \\
\text { Example: } \\
\text { Tы приятно пахнешь. } \\
\text { (You smell good.) }\end{array}$ & $\begin{array}{l}P R O+A D V+V \\
\text { Example: } \\
\text { Tu гарно nосміхаєuся. } \\
\text { (You smile beautifully) }\end{array}$ & $\begin{array}{l}\text { PRO+VERB+ } \\
\text { COMPLEMENT } \\
\text { Example: } \\
\text { I wish I had your legs. } \\
\text { You are all legs! }\end{array}$ \\
\hline
\end{tabular}

During this study, the most frequent patterns identified were:

Ukrainian: PRO + (intensifier) + ADJ $(28,1 \%)$. Ukrainian compliments used this pattern and PREP+PRO + HAVE + (intensifier) ADJ + N/NP (22\%): Ти дуже непередбачувана (You are very unpredictable). У тебе дуже гарні очі (You have very beautiful eyes)

Russian: PRO+HAVE+ADJ+N/NP (18.6\%): У тебя красивые глаза. (You have beautiful eyes.)

American English: PRO+BE+ADJ+COMPLEMENT (26\%) and $\mathrm{PRO} / \mathrm{NP}+\mathrm{LOOK}+\mathrm{ADJ}+\mathrm{COMPLEMENT}$ (26\%): You're awesome. You're a 10/10, for real, you're so beautiful. You look really professional in that outfit-I love the cardigan.

Some other patters that resulted in a minor frequency were:

Ukrainian: You are (my) +THE MOST+ADJ+N (0,4\%), NP + VERB + ADJ +COMPLEMENT $(0,4 \%)$, and PREPOSITIONAL PHRASE + NP (0,4\%): Tи найкращча подруга в світі (You are the best friend in the world). Пиріг приготований просто чудово (Pie is cooked absolutely great). Ha тобі дуже гарні прикраси (You have very beautiful jewelry).

Russian: $\mathrm{N}+\mathrm{ADV}+\mathrm{V}(1,1 \%)$ and ADV (intensifier) + ADJ $(1,5 \%)$ : Очень красивая. (Very beautiful). Платье очень хорочо скроено (The dress is cut out very well). 


\section{American English:}

$\mathrm{NP}+\mathrm{BE}+\mathrm{ADJ}+\mathrm{COMPLEMENT} \mathrm{(1 \% ):} \mathrm{The} \mathrm{food} \mathrm{was} \mathrm{great!} \mathrm{The} \mathrm{pastor} \mathrm{is}$ a wonderful preacher.

IMPERATIVE VERB+COMPLEMENT (1\%): Look at you!!! Go Luis! Great job, keep up the good work!

IDIOMATIC EXPRESSION (1\%): Way to go. Congrats.

QUESTION+COMPLEMENT (1\%): Can you try not to be so awesome? You are making the rest of us look bad. INTERJECTION+NP (1\%): Bravo, my intellectual friend!

Both types of compliments also used a limited number of syntactic patterns although the Ukrainian compliments were more varied in their syntactic form. The Ukrainian and Russian data set included compliment forms that did not occur in the American data, the Ukrainian and Russian data included one-word compliments, whereas the American data did not:

Ukrainian: ADJ (3,8\%): Розумний (Smart). Мила (Cute). N (1,7\%): Красуня (Веаиty). Молодецьь (Well done).

Russian: ADJ (3,3\%): Красивая (Beautiful). N (2,2\%): Молодеи (Good job.)

In addition, some other patterns of Ukrainian compliments were identified which are not used in Russian and American English. These expressions start with particle Як, Який. Яка (How). That accounted 3,2\%: Який (how) + HAVE + (intensifier) ADJ + N (1,2\%): Яка в тебе чудова сукня! (How beautiful dress you have). Яка (how) + ADJ + N (1,2\%): Яка чудова погода (How great weather is). Яка (how) + ADJ/PRO + N (0,8\%): Яка ти красуня (How pretty уои are).

\section{Compliment length}

The compliment length is the approximate number of words that each compliment showed in this study. These results showed a very interesting aspect that is the existence of simple and complex compliments. The simple compliments are those formed by one sentence or expression with a single compliment that denotes the flattery impact, and all together makes the meaning.

Table 2

Compliment length

\begin{tabular}{|c|c|c|}
\hline Russian compliments & $\begin{array}{c}\text { Ukrainian } \\
\text { compliments }\end{array}$ & English compliments \\
\hline 5,9 words & 4,32 words & 5,5 words \\
$(445$ compliments - & $(231$ compliments - & $(245$ compliments - \\
2025 words $)$ & 1263 words $)$ & 1360 words $)$ \\
\hline
\end{tabular}


Examples of simple and complex compliments

\begin{tabular}{|c|c|c|}
\hline $\begin{array}{l}\text { Simple compliments: } \\
\text { Tbl прекрасна! (You } \\
\text { are so beautiful!) }\end{array}$ & $\begin{array}{l}\text { Simple compliments: } \\
\text { Дуже гарно! } \\
\text { (Very nice!) }\end{array}$ & $\begin{array}{l}\text { Simple compliments: } \\
\text { Hey beautiful! } \\
\text { Excellent report! }\end{array}$ \\
\hline Complex & Complex & Complex \\
\hline compliments: & compliments: & compliments: \\
\hline Ты очень умная и & Ви дуже гарна та & So honored to work \\
\hline красивая девушка ия & загадкова & with such great and \\
\hline хочу быть с тобой & незнайомка, але циі & talented future \\
\hline рядом каждую & квіти я купив саме & English teachers, \\
\hline секунду (You are a & для Вас (You are very & translators, \\
\hline very smart and & beautiful and & interpreters and \\
\hline beautiful girl and I & mysterious woman, & philologists from \\
\hline want to be with you & but I bought these & Ukraine!!! \\
\hline every second) & flowers for you). & Got the privilege to \\
\hline В Ваших глазах & В тебе дуже гарна & visit and listen to the \\
\hline можно кататься на & посмішка! & awesome \\
\hline яхте потому, что & Посміхайся частіше & presentations from \\
\hline они как два океана & (You have beautiful & these bright kids!! \\
\hline (In your eyes I can & smile! Smile more & I feel excited to work \\
\hline $\begin{array}{l}\text { sale because they are } \\
\text { like two oceans). }\end{array}$ & often!). & $\begin{array}{l}\text { with them and I look } \\
\text { forward to it! }\end{array}$ \\
\hline
\end{tabular}

\section{Adjectives}

It is also interesting to show the results found in this study in terms of adjectives. Most of all the compliments found in three languages were adjectival. The adjectives found in the American compliments were varied. 44 different types of adjectives were identified. The most usual were, good (+the best) $19 \%$, great $14,9 \%$. nice 9,2\%, beautiful 9,2\%, awesome $5,1 \%$, amazing $3,6 \%$, cute $3 \%$, wonderful $2,6 \%$, pretty $2,6 \%$ handsome $2 \%$, smart $2 \%$. These 11 adjectives accounted $76,3 \%$.

In the study 35 different adjectives in Ukrainian compliments were identified. 10 the most frequent Ukrainian adjectives $(84,9 \%)$ are: гарний(pretty) 25,2\%, розумний (smart) 15, 4\%, вродливий (beautiful) 10,3\%, добрий (good, kind) 8,1\%, смачний (tasty) 7,5\%, щуирий (sincere) 6\%, турботливий (thoughtful) 3,5\%, хазяйновитий (handy) 3,4\%, найкращий (best) 3\%, веселий (jolly) 2,5\%.

The amount of Russian adjective is almost the same as American ones. 45 different adjectives are identified and $11(61,9 \%)$ of them are the most frequent in use. Among them: красивыц (pretty) 31,5\%, умный (smart) 
$5,1 \%$, иикарный (elegant) 3,5\%, прекрасный (beautiful) 3,5\%, вкусный (tasty) $3.2 \%$, мильй (nice) $2.8 \%$, хороший (good) 2.8\%, отличный (excellent) 2,2, крутой / классный (cool) 2.2\%, лучший (best) 1,9\%, добрый(kind) $1,9 \%$.

\section{Verbs}

In this study in the American compliments, the most usual (6 verbs from 10) were: to look (33.3\%), to like (22.2\%), to have (13.3), to love (11.1\%), to do $(11.1 \%)$. Other verbs $(9 \%)$ are found in a minor frequency. In the Ukrainian compliments were found 6 verbs from 21 the most frequent in use: nасувати/ личити (to suit) 10\%, виглядати (to look) 26\%, мати (to have) 10\%, подобатися (to like) 11,2\%, пахнути (to smell) 8\%, робити (to do) 14\%. In the Russian compliments, 16 different verbs were found and the most usual were: выглядеть (to look) 31.8\%, идти/ подходит (to suit) 13.2\%, нравится (to like) 9.7\%, готовить (to cook) $7.07 \%$, любить (to love) $2.6 \%$.

\section{Adverbs}

Ukrainian and Russian compliments are characterized by using of a great number of adverbs: 18 different adverbs in 171 from 231 Ukrainian compliments, 26 different adverbs in 95 from 445 Russian compliments. In comparison, 5 different adverbs in 28 from 245 English compliments were found.

\section{Tone employed}

During this study, it was identified and analyzed the tone used in the compliments. The kinds of tone were classified in: positive or sincere way and negative or sarcastic way. A $98 \%$ of the compliments were told sincerely by Americans. Females (2\%) and males (2.2\%) told compliments sarcastically. In the Ukrainian compliments a 97\% (Russian compliments 98\%) was sincere and a 3\% (Russian compliments - 2\%) was sarcastic in general. Ukrainian speaking females said a 98,2\% (Russian speaking females - 99.1\%) of the compliments sincerely and a $1.8 \%$ (Russian speaking females $-0.8 \%$ ) sarcastically, whereas Ukrainian speaking males said a $95.5 \%$ of the compliments sincerely (Russian speaking males - 96\%) and a $4.5 \%$ sarcastically (Russian speaking males $-4 \%$ ).

\section{Attributes praised}

First of all, it is important to mention the categories used in this study. Such categories were called: "appearance", "traits/personality", "skill/work", "personal property", and "other". Also, all these attributes were branched in order to give a clearer vision of each category as follows:

A. Appearance. It involves the general looks of the persons involved. It was subdivided in: "general appearance" that is a general subdivision because it involved somebody's whole appearance referred to the body or clothe, not praising a specific part of the person. Another subdivision was: 
"body", that involves any part of the body where in American compliments are praised: hair, eyes, feet, calves, and butt, whereas in Ukrainian compliments are praised: eyes, smile, hair (haircut, hairdo, hairstyle, hair color), voice (timbre, laugh), figure, nails (manicure), face, age. In Russian compliments to this list the following can be added: eyelashes, eyebrows and tattoos.

Another subdivision was: "clothes" that are all the items that perform a good or bad look in the persons, are used in the body, and they can be directly identified. Americans praised: skirts, dresses, pants, shoes, shirts, glasses, sweaters, and bags; whereas in Ukrainian compliments are praised more assessors, and makeup, in Russian compliments - style (new image, cool image, fashionable, good taste).

B. Traits/personality. It involves the general personality of the persons. It also was subdivided in: "personality" that is the way a person behaves in a negative or positive way. Personal traits that are praised in Russian compliments: faithful, devoted, native soul, strange, cool, kindhearted, funny, cheerful, nice, charismatic, sincere, open, positive, mystic, brave, active, sociable, artistic, sense of humor, taking difficulties easy; in Ukrainian compliments: cool, kindhearted, funny, cheerful, nice, charismatic, sincere, open, positive, mystic, brave, sociable, artistic, sense of humor, vulnerable, mysterious, honest, curious, awesome, caring, communicative; in English compliments: talented, active, friendly, hardworking, cool, funny, cheerful, nice, sincere, positive, brave, sociable, artistic, sense of humor, taking difficulties easy.

C. Skills/work. It involves the general abilities of any person to perform any activity or job. It was subdivided in: "job well done" that is any wellperformed activity in the job and the school. Another subdivision is: "good meal or taste" that is the capacity to cook, and "skill/effort that denotes someone's general skill to do something. In American, Ukrainian and Russian compliments these 3 subdivisions were complimented.

D. Personal property. It involves items not being used by the person on his/her body, those can be houses, cars, cats, dogs, etc., and items that are not identified or seen in the person's body. Americans praised an outfit, a new car, whereas praised a perfume, which was not directly seen or identified because it was a smell, a fragrance.

E. Other. This category refers to any compliment that did not fit in the previous classifications. It was identified in compliments in the Ukrainian/Russian data (poem, song, decoration) and English data (photo in social network/blog post, attention/presence). In the table, all the results are exemplified in terms of attributes praised found in this study in the Russian, Ukrainian and English compliments. 
Table 4

Attributes praised by Russian, Ukrainian \& English compliments

\begin{tabular}{|c|c|c|c|c|c|c|}
\hline \multicolumn{7}{|c|}{ Russian compliments } \\
\hline $\begin{array}{c}\text { Appea- } \\
\text { rance }\end{array}$ & $\begin{array}{c}\text { Traits/ } \\
\text { Persona- } \\
\text { lity }\end{array}$ & $\begin{array}{c}\text { Skill/ } \\
\text { work }\end{array}$ & Taste & $\begin{array}{c}\text { Natural } \\
\text { Human } \\
\text { Traits }\end{array}$ & Other & Total \\
\hline $\begin{array}{c}164 \\
(36,8 \%)\end{array}$ & $\begin{array}{c}100 \\
(22,4 \%)\end{array}$ & $\begin{array}{c}58 \\
(13 \%)\end{array}$ & $\begin{array}{c}54 \\
(12,1 \%)\end{array}$ & $\begin{array}{c}58 \\
(13 \%)\end{array}$ & $\begin{array}{c}9 \\
(2 \%)\end{array}$ & $\begin{array}{c}445 \\
(100 \%)\end{array}$ \\
\hline \multicolumn{7}{|c|}{ Ukrainian compliments } \\
\hline $\begin{array}{c}\text { Appea- } \\
\text { rance }\end{array}$ & $\begin{array}{c}\text { Traits/ } \\
\text { persona- } \\
\text { lity }\end{array}$ & $\begin{array}{c}\text { Skill/ } \\
\text { Work }\end{array}$ & $\begin{array}{c}\text { Personal } \\
\text { property }\end{array}$ & $\begin{array}{c}\text { Natural } \\
\text { Human } \\
\text { Traits }\end{array}$ & Other & Total \\
\hline $\begin{array}{c}98 \\
(42,4 \%)\end{array}$ & $\begin{array}{c}28 \\
(12 \%)\end{array}$ & $\begin{array}{c}16 \\
(7 \%)\end{array}$ & $\begin{array}{c}22 \\
(9,5 \%)\end{array}$ & $\begin{array}{c}62 \\
(27 \%)\end{array}$ & $\begin{array}{c}5 \\
(2,1 \%)\end{array}$ & $\begin{array}{c}231 \\
(100 \%)\end{array}$ \\
\hline \multicolumn{7}{|c|}{ English compliments } \\
\hline $\begin{array}{c}\text { Appea- } \\
\text { rance }\end{array}$ & $\begin{array}{c}\text { Traits/ } \\
\text { Personality }\end{array}$ & $\begin{array}{c}\text { Skill/ } \\
\text { work }\end{array}$ & $\begin{array}{c}\text { Personal } \\
\text { property }\end{array}$ & Other & Total \\
\hline $\begin{array}{c}50 \\
(20,4 \%)\end{array}$ & $\begin{array}{c}40 \\
(16,2 \%)\end{array}$ & $\begin{array}{c}92 \\
(36,45 \%)\end{array}$ & $\begin{array}{c}36 \\
(14,7 \%)\end{array}$ & $\begin{array}{c}27 \\
(10,95 \%)\end{array}$ & $\begin{array}{c}245 \\
(100 \%)\end{array}$ \\
\hline
\end{tabular}

Gender of the compliment giver and receiver. According to the data American females complimented both males and females in appearance, but they also praised more males in personality and in skill/work, but not in the category: property and other. American males complimented more males in skill/work but females in appearance. They praised both females and males only in traits/personality. Only one compliment was given to males in property but none to females in this category.

In contrast, Ukrainian females complimented more females in appearance, and males to traits/personality, and in property, although both females and males were complimented in skill/work. Concerning the Ukrainian males (Russian and Ukrainian speakers), they extremely complimented females in appearance, traits/personality, and in skill/work but not in other and property. Males were less praised in appearance, personality, and the category other and none in skill/work and property.

Finally, it is important to mention that Ukrainian males (Russian and Ukrainian speakers) praised females even more than American males to females. Ukrainian females (Russian and Ukrainian speakers) complimented females more than American females to females, but American males 
praised males a lot because it is very normal in the American culture. However, it is not common in Ukraine to see males complimenting other male so if they do it, it is performed in a sarcastic way. In the relationship female to male, both cultures praised almost the same number of males. Also, it is usual for American culture to compliment to a group of people or an even.

Table 5

Attributes praised in compliments

\begin{tabular}{|c|c|c|c|c|c|c|}
\hline \multicolumn{7}{|c|}{ Russian speaking participants } \\
\hline Gender & $\begin{array}{c}\text { Appea- } \\
\text { rance }\end{array}$ & $\begin{array}{c}\text { Traits/ } \\
\text { persona- } \\
\text { lity }\end{array}$ & $\begin{array}{c}\text { Skill/ } \\
\text { work }\end{array}$ & Taste & $\begin{array}{c}\text { Natural } \\
\text { Human } \\
\text { Traits }\end{array}$ & Other \\
\hline Total & $\begin{array}{c}164 \\
(36,8 \%)\end{array}$ & $\begin{array}{c}100 \\
(22,4 \%)\end{array}$ & $\begin{array}{c}58 \\
(13 \%)\end{array}$ & $\begin{array}{c}54 \\
(12 \%)\end{array}$ & $\begin{array}{c}58 \\
(13 \%)\end{array}$ & $\begin{array}{c}9 \\
(2 \%)\end{array}$ \\
\hline \multicolumn{7}{|c|}{ Ukrainian speaking participants } \\
\hline Gender & $\begin{array}{c}\text { Appea- } \\
\text { rance }\end{array}$ & $\begin{array}{c}\text { Traits/ } \\
\text { personality }\end{array}$ & $\begin{array}{c}\text { Skill/ } \\
\text { work }\end{array}$ & $\begin{array}{c}\text { Personal } \\
\text { property }\end{array}$ & Other \\
\hline Total & $\begin{array}{c}98 \\
(42.4 \%)\end{array}$ & $\begin{array}{c}28 \\
(12 \%)\end{array}$ & $\begin{array}{c}16 \\
(7 \%)\end{array}$ & $\begin{array}{c}22 \\
(9.5 \%)\end{array}$ & $\begin{array}{c}62 \\
(27 \%)\end{array}$ \\
\hline \multicolumn{7}{|c|}{ American English speaking participants } \\
\hline Total & $\begin{array}{c}50 \\
(20,4 \%)\end{array}$ & $\begin{array}{c}40 \\
(16,2 \%)\end{array}$ & $\begin{array}{c}92 \\
(36,45 \%)\end{array}$ & $\begin{array}{c}36 \\
(14,7 \%)\end{array}$ & $\begin{array}{c}27 \\
(10,95 \%)\end{array}$ \\
\hline
\end{tabular}

Role relationship between the compliment giver and receiver. First, it is essential to mention the scheme used in this study to categorize the relationship between the participants. The categories used were relatives that cover all the family members; acquaintances that cover classmates, coworkers, teacher/student relationships, boss/employer relationship, casual acquaintances, neighbors, and customer/worker relationships. Another category was friends that covers friends and roommates; intimates who are boyfriends or husband/wife only; the category strangers, who are totally unknown people, and the category other, referred to a relationship different to these ones.

The results indicated that both Americans and Ukrainians (Russian and Ukrainian speaking participants) praised friends, Americans with a $28.5 \%$ and Ukrainians with 36,3\% (Ukrainian speaking participants) and 35.5\% (Russian speaking participants). Americans complimented then: acquaintances, including classmates, coworkers, teacher/student, 
boss/employer, casual acquaintances and customer/worker with a $22 \%$ whereas Ukrainians praised a 16.5-17.3\%, including all the subcategories mentioned above, plus neighbors. However, Americans did not praise strangers $(10.1 \%)$, as much as Ukrainians did (Ukrainian speaking participants $-9 \%$, Russian speaking $-6 / 9 \%$ participants). In addition, Americans only praised intimates, with a $7.4 \%$, whereas Ukrainians did it with a $14.6 \%$ (Ukrainian speaking participant) and $13.9 \%$ (Russian speaking participants). Ukrainians praised relatives with a $14.3 \%$ (Russian speaking participants) and a $10.8 \%$ (Ukrainian speaking participants) although Americans did it with a $11.8 \%$. Consequently, Ukrainians praised more intimates, friends and acquaintances than Americans, but both nationalities don't praise strangers.

\section{Compliment frequency}

The results show that Americans complimented an average every 58 hours ( 2 days and 10 hours), Russian speakers - every 134.5 hours (5 days), and Ukrainian speakers - every 37 hours (1 day and 13 hours). According to the results in compliment frequency, Ukrainian speaker are more expressive than English and Russian speakers and more open in communication.

\section{CONCLUSIONS}

In this research there were investigated the ways of complimenting in Ukrainian, Russian and American English to avoid misunderstandings and pragmatic failure. American, Ukrainian and English compliments were compared in order to know the patterns being used by the speakers: compliment frequency; attributes praised; role relationship between the speakers; gender of the speakers; tone used and compliment form that includes: number of words, adjectives and verbs used in the compliments.

As we have observed in these preliminary results, there exist numerous implications from this study into pragmatics competence. We can see the importance of understanding the syntactical formulas in the three languages. It will help L2 speakers to avoid pragma-linguistic failure. Communicators wishing to produce these speech acts can better understand the structure of the expressions and follow the aforementioned formulas. Adjectives are also important to consider as part of the cultural lexicon used within those languages and utilize those that are the most familiar in the second language context. Another important aspect is paying attention to the attributes praised and see how native speakers of English (living in the USA), Russian and Ukrainian (living in Ukraine), tend to compliment people. These results also allow speakers to take a glance through a window into the cultures where these languages are used, and see what is valued by different nations in different situations. 
Upon completion of the data analysis on the current study, further information on variables such as role relationship of the giver and receiver of the compliment, attributes praised by gender according to nationality, some factors of meaning toward the compliments, to avoid false interpretations of the compliments, and even a deeper analysis in terms of semantics, metaphorical language can be provided.

\section{SUMMARY}

Compliments as speech acts have the reflection and expression of cultural values. Many of the values reflected through compliments are personal appearance, new acquisitions, possessions, talents and skills. It is especially important in linguistic interaction between people. This research aims to analyze the speech acts of complimenting in Ukrainian and American cultures. Defining the ways of complimenting in Ukrainian, Russian and American English help to avoid misunderstandings and pragmatic failures. This study uses a method of ethnomethodology. Speech acts are studied in their natural contexts. To carry out this research native speakers of English in the United States and native speakers of Russian and Ukrainian from all over Ukraine were interviewed on-line. The analysis was made on the data that included: 445 Russian, 231 Ukrainian and 245 English compliments. Results of this study show how native speakers tend to compliment people: syntactical structure of expressions, cultural lexicon, attributes praised and language context. Knowing how to use speech acts allows the speaker to have pragmatic competence. Upon completion of the data analysis on the current study, further information on deeper analysis in terms of semantics and metaphorical language can be provided.

\section{REFERENCES}

1. Aceves P. (1996) A Comparative Study of the Use of "Compliments" by Native Speakers of American English and Native Speakers of Mexican Spanish, Puebla: Universidad de las Americas.

2. Allami H., \& Naeimi A. (2011) A cross-linguistic study of refusals: An analysis of pragmatic competence development in Iranian EFL learners. Journal of Pragmatics, vol. 43, pp. 385-406.

3. Al Rawashdeh Al Balqa B. (2018) Arabic Jordanian compliment (Mujamaleh) and politeness online expressions versus their counterparts in American English. Journal of Education and Practice, no. 9 (33). Retrived from: https://iiste.org/Journals/index.php/JEP/article/viewFile/45277/46721 (accessed 2 May 2020)

4. Austin J. L. (1975) How to Do Things with Words, Second Edition, Oxford: Oxford University Press. 
5. Barnlund D. C. \& Araki S. (1985) Intercultural encounters: The management of compliments by Japanese and Americans. Journal of Cross-Cultural Psychology, no. 16 (1), pp. 9-26.

6. Beebe L. M., Takahashi, T. \& Uliss-Weltz R. (1990) Pragmatic transfer in ESL refusals. In R. C. Scarcella, E. S. Andersen \& S. D. Krashen (Eds.) Developing Communicative Competence in a Second Language (pp. 55-73). New York: Newbury House Publishers.

7. Bialystok E. (1993) Symbolic representation and attentional control in pragmatic competence. In Kasper, G., \& Blum-Kulka, S. (Eds.). Interlanguage Pragmatics (pp. 43-57). Oxford: Oxford University Press.

8. Canale M. \& Swain M. (1980) Theoretical bases of communicative approach to second language teaching and testing. Applied Linguistics, no. 1, pp. 1-47.

9. Chung-Hye H. (1992) A comparative study of compliment responses: Korean females in Korea interactions and in English interactions. Working Papers in Educational Linguistics, no. 8 (2), pp. 17-31.

10. Farshi S. \& Baghbani S. (2015) The effects of implicit and explicit focus on form on oral accuracy of EFL learners. Theory and Practice in Language Studies, no. 5 (2), pp. 292-297.

11. Fetterman D.M. (1989) Ethnography Step by Step, Newbury Park, CA. Sage.

12. Fraser B. (1990) Perspectives on Politeness. Journal of Pragmatics, no. 14 , pp. 219-236.

13. Halenko N. \& Jones C. (2011) Teaching pragmatic awareness of spoken requests to Chinese EAP learners in the UK: Is explicit instruction effective system. Technology and Applied Linguistics, no. 39, pp. 240-250.

14. Herbert R. (1990). Sex-based differences in compliment behavior. Language in Society, no. 19, pp. 201-224.

15. Herbert R. \& Straight H.S. (1989). Compliment-rejection versus compliment avoidance: listener-based versus speaker-based pragmatic strategies. Language \& Communication, no. 9, pp. 35-47.

16. Holmes J. (1988) Paying compliments: A sex preferential positive politeness strategy. Journal of Pragmatics, no. 12 (3), pp. 445-465.

17. Holmes J. \& Brown D.F. (1987) Teachers and students learning about compliments. TESOL Quarterly, no. 21 (3), pp. 523-546.

18. Kasper G. (2001) Classroom research on interlanguage pragmatics. In Kasper, G., \& Rose, K. (Eds.). Pragmatics and Language Teaching, (pp. 33-60). Cambridge: Cambridge University Press.

19. Manes J. (1983) Compliments: A mirror of cultural values. In N. Wolfson and E. Judd (Eds.), Sociolinguistics and Language Acquisition (pp. 82-95). Rowley, MA: Newbury House. 
20. Manes J. \& Wolfson N. (1981) The compliment formula. In F. Coulmas (Ed.) Conversational Routine: Explorations in Standardized Communication Situations and Prepatterned Speech (pp. 116-132). The Hague, the Netherlands: Mouton Publishers.

21. Loiseau M., Hallal R., Ballot P. \& Gazidedja (2016) A. Game of Words: prototype of a digital game focusing on oral production (and comprehension) through asynchronous interaction. Retrived from: https://files.eric.ed.gov/fulltext/ ED572202.pdf (accessed 2 May 2020).

22. Nelligan M. (1996). El Picaro Mexicano, Mexico, D.F.: Diana.

23. Nelson G., Al-Batal M. \& Echols E. (1996). Arabic and English Compliment responses: Potential for Pragmatic failure. Applied Linguistics, no. 17 (4), pp. 411-432.

24. Nelson G. (1993) Egyptian and American Compliments: A crosscultural study. International Journal of Intercultural Relations, no. 17, pp. 293-313.

25. Nguyen T., Pham, T. \& Pham, M. (2012) The relative effects of explicit and implicit form-focused instruction on the development of L2 pragmatic competence. Journal of Pragmatics, no. 44, pp. 416-434.

26. Nordquist R. (2017) Pragmatic Competence: Glossary of Grammatical and Rhetorical Terms. Retrived from https://www.thoughtco.com/ pragmatic-competence-1691653 (accessed 2 May 2020).

27. Perea-Hernandez J.L. (2010) Teacher Evaluation of Item Formats for an English Language Proficiency Assessment. Dissertations and Theses. Retrieved from: https://pdxscholar.library.pdx.edu/open_access_ etds/436/ (accessed 2 May 2020)

28. Perea-Hernandez, J.L. (2017). You are like steel wrapped in silk!: a comparative study of conceptual metaphor in Peninsular \& Latin American Spanish piropos and English pick up lines. In Культурно-детерміновані Фактори у Практииі Перекладу: Монографія, ed. by Solodka A. (pp.122-165). Mykolaiv. Retrived from: https://pdx.academia.edu/LuisPerea (accessed 2 May 2020).

29. Rajabi S. \& Farahian M. (2013) The effects of pragmatic instruction on EFL learners' awareness of suggestions. Modern Journal of Language Teaching Methods, no. 3 (3), pp. 28-38.

30. Shi X. (2014) On cross-cultural pragmatic failures in $\mathrm{C} / \mathrm{E}$ interpretation. Theory and Practice in Language Studies, no. 4(5), pp. 1033-1037.

31. Solak E. \& Bayar A. (2015) Current challenges in English Language Learning in Turkish EFL context. Participatory Educational Research, no. 2 (1), pp. 106-115. 
32. Thomas J. (1983) Cross-cultural pragmatic failure. Applied Linguistics, no. 4, pp. 91-112.

33. Valdés G. (1981) Codeswitching as a Deliberate Verbal Strategy: A Microanalysis of Direct and Indirect Requests among Bilingual Chicano Speakers. In Latino Language and Communicative Behavior, ed. by Richard P. Durán (pp. 95-107). Norwood, NJ: Ablex.

34. Van Dijk T. (1985) Handbook of Discourse Analysis, London: Academic Press.

35. Wierzbicka A. (1991) Cross-cultural Pragmatics: The Semantics of Human Interaction. In Trends in Linguistics: Studies and Monographs.

36. Wolfson N. (1983) An empirically based analysis of complimenting behavior in American English. In N.Wlfson \& E.Judd (Eds.). In Socioliguistics and Language Acquisition (pp. 82-95). Rowley, MA: Newbury House.

37. Wolfson N. (1988) The bulge: a theory of speech behavior and social distance. In Fine, J. (ed) Second Language Discourse: A Textbook of Current Research (pp. 17-34). Norwood, NJ: Ablex.

38. Wolfson N. \& Manes J. (1980) Compliment as social strategy. International Journal of Human Communication, no. 13, pp. 391-410.

\section{Information about the authors:}

Solodka A. K.,

Dr hab., Professor at the Department of German Philology and Translation, V.O. Sukhomlynsky National University of Mykolaiv 24, Nikolska str., Mykolaiv, 54000, Ukraine ORCID ID: orcid.org/0000-0003-1703-7996

Luis Perea, Lecturer,

Department of Bilingual Bicultural, Studies at University of Texas at San Antonio, USA ORCID ID: orcid.org/0000-0002-9353-5738 